\title{
PENERAPAN MODEL KOOPERATIF TIPE TEAM ACCELERATED INTRUCTION (TAI) UNTUK MENINGKATKAN KEAKTIFAN DAN HASIL BELAJAR PESERTA DIDIK PADA PEMBELAJARAN TEMATIK
}

\author{
Aden Muhammad Kosasih, M.Pd ${ }^{1}$ \\ Sri Mulyani² \\ 1 STKIP Subang \\ 2Mahasiswa PGSD FKIP Unpas
}

\begin{abstract}
This study aims to improve students' activity and learning outcomes by using Cooperative Learning model of Team Accelerated Intruction (TAI) type on the theme of the togetherness of my nation's cultural diversity subtema. This research is conducted in class IV SDN Komplek Karang Taruna Sari and background of student condition which show less activity in group process and result of learning which still many criteria of minimal mastery because teacher often use lecture motto which tend monoton and not yet use model Cooperative Learning Type Team Accelerated Intruction (TAI) consists of 8 phases: pretest, brief material, heterogeneous small group, group work group, presentation of group work, posttest, best group setting, and formative test. Assessment used in this research is pretest and posttest test technique to know student learning result, activeness assessment and observation sheet to know teacher and student attitudes during learning process. The results showed an increase in the average of the assessment of liveliness and learning test results. On the assessment of the activity of the average value of cycle 1 is 57.73 while cycle 2 reaches 67.31 and 3 cycles reaches 82.01 Learning outcomes in cycle 1 average score of 65.66, in cycle 2 reaches 70.16 and Learning outcomes in cycle 3 reached 76.33. This shows that the use of Cooperative Learning Model Type Team Accelerated Intruction (TAI) can improve the activity and learning outcomes of students on the theme of togetherness subtema cultural diversity of my nation class IV SDN Komplek Karang Taruna Sari. Thus, the use of Cooperative Learning model of Team Accelerated Intruction (TAI) type can be used as a learning model to be applied to thematic learning with other themes and subthemes.
\end{abstract}

Keywords: Cooperative Learning Type TAl, liveliness, learning outcomes.

\section{ABSTRAK}

Penelitian ini bertujuan untuk meningkatkan keaktifan dan hasil belajar siswa dengan menggunakan model Cooperative Learning tipe Team Accelerated Intruction (TAl) pada tema indahnya kebersamaan subtema keberagaman budaya bangsaku. Penelitian ini dilaksanakan dikelas IV SDN Komplek Karang Taruna Sari dan dilatar belakangi keadaan siswa yang kurang menunjukkan keaktifan di dalam proses kerja kelompok dan hasil belajar yang 
masih banyak kriteria ketuntasan minimal karena guru sering menggunakan motode ceramah yang cenderung monoton dan belum menggunakan model Cooperative Learning Tipe Team Accelerated Intruction (TAI) yaitu terdiri 8 fase yaitu melakukan pretest, memberikan materi secara singkat, membentuk kelompok kecil yang heterogen, mengerjakan LKS secara berkelompok, mempresentasikan hasil kerja kelompok, memberikan postest, menetapkan kelompok terbaik, dan memberikan tes formatif. Penilaian yang digunakan pada penelitian ini adalah teknik tes pretest dan postest untuk mengetahui hasil belajar siswa, penilaian keaktifan dan lembar observasi untuk mengetahui kegaiatan guru dan siswa selama proses pembelajaran. Hasil penelitian menunjukkan adanya peningkatan rata-rata dari penilaian keaktifan dan hasil tes belajar. Pada penilaian keaktifan nilai rata-rata siklus 1 yaitu 57,73 sedangkan siklus 2 mencapai 67,31 dan siklus 3 mencapai 82,01 Hasil belajar pada siklus 1 nilai rata-rata yaitu sebesar 65,66, pada siklus 2 mencapai 70,16 dan hasil belajar pada siklus 3 mencapai 76,33. Hal ini menunjukkan bahwa penggunaan model Cooperative Learning Tipe Team Accelerated Intruction (TAI) dapat meningkatkan keaktifan dan hasil belajar siswa pada tema indahnya kebersamaan subtema keberagaman budaya bangsaku kelas IV SDN Komplek Karang Taruna Sari. Dengan demikian, penggunaan model Cooperative Learning tipe Team Accelerated Intruction (TAI) dapat dijadikan salah satu model pembelajaran untuk diterapkan pada pembelajaran tematik dengan tema dan subtema yang lainnya.

Kata kunci: Cooperative Learning Tipe TAI, keaktifan, hasil belajar.

\section{A. PENDAhULUAN}

Pendidikan sebagai sektor
yang paling penting dalam
meningkatkan kualitas hidup.
Pendidikan juga dipandang
sebagai salah satu aspek yang
memiliki peran pokok membentuk
manusia yang akan datang.
Dengan pendidikan diharapkan
dapat menghasilkan manusia
berkualitas dan mampu bersaing di
masa depan.
Tujuan
mengarahkan pada pembentukkan

manusia Indonesia seutuhnya. Hal ini dijelaskan dalam Undangundang Republik Indonesia Nomor 20 tahun 2003 tentang Sistem Pendidikan Nasional pasal 3 ayat 1 menjelaskan sebagai berikut: Pendidikan nasional berfungsi mengembangkan peradaban bangsa yang bermartabat dalam rangka mencerdaskan kehidupan bangsa, bertujuan untuk mengembangkan potensi peserta didik agar menjadi manusia yang beriman dan bertakwa kepada 
Tuhan Yang Maha Esa, berakhlak mulia, sehat, berilmu, cakap, kreatif, mandiri, dan menjadi warga Negara yang demokratis serta bertanggungjawab

Jadi pendidikan dapat dimaknai sebagai proses mengubah tingkah laku peserta didik agar menjadi manusia dewasa yang mampu hidup mandiri sebagai anggota masyarakat dalam lingkungan alam sekitar dimana individu tersebut berada.

Kurikulum merupakan alat penting dalam proses pendidikan untuk mencapai tujuan pendidikan Kurikulum 2013 adalah kurikulum baru yang dicetuskan oleh Kementerian Pendidikan dan Kebudayaan RI untuk menggantikan Kurikulum Tingkat Satuan Pendidikan (KTSP) yang diterapkan sejak 2006 lalu. Kurikulum 2013 merupakan sebuah kurikulum yang mengutamakan pemahaman, skill, kemampuan dan pendidikan berkarakter. Peserta didik dituntut untuk paham atas materi, aktif dalam berdiskusi dan presentasi serta memiliki sopan santun dan disiplin yang tinggi.
Pengembangan Kurikulum 2013 merupakan langkah lanjutan dari KTSP (Kurikulum Tingkat Satuan Pendidikan) dan pengembangan KBK (Kurikulum Berbasis Kompetensi) yang mempunyai beberapa kelebihan, diantaranya, karakteristik individual peserta didik terakomodir karena menggunakan sistem pembelajaran tuntas, terjaminnya obyektivitas penilaian, dan kualitas lulusan relatif lebih baik. Hal tersebut karena parameter keberhasilan belajar peserta didik dalam kurikulum 2013, dilihat dari basis kompetensi, yang menekankan pada keseimbangan soft skill, kecakapan dalam hal nilainilai yang melekat pada seseorang, dan hard skill, kemampuan akademik, para siswa yang mencakup kompetensi sikap, pengetahuan, dan keterampilan secara terpadu. Melalui sistem ini para peserta didik, dididik sampai memenuhi kompetensi kelulusan sehingga dapat memenuhi apa yang di harapkan oleh lapangan pekerjaan. 


\begin{abstract}
Dalam kurikulum 2013, sasaran pembelajaran telah memenuhi tiga ranah yang sesuai dengan Standar Kompetensi Lulusan (SKL) yang seharusnya ada pada diri peserta didik, yaitu ranah pognitif(pengetahuan), ranah psikomotorik (keterampilan), serta ranah afektif (sikap). Dalam pembelajaran tematik terdapat masalah-masalah yang timbul yaitu diantaranya: Kegiatan inti pembelajaran tematik melalui lima tahapan pembelajaran yaitu kegiatan mengamati, menanya, mengasosiasikan, mencoba dan membagun jejaring. Pelaksanaan pembelajaran di SD terbagi pada tema. Setiap tema terbagi menjadi sub tema dan setiap subtema terbagi menjadi pembelajaran 1 sampai dengan pembelajaran 6 . Dengan demikian dapat dikatakan bahwa setiap hari setiap kelas akan mendapatkankan satu kegiatan pembelajaran dalam sehari. Satu kegiatan pembelajaran merupakan pembelajaran tematik sebagai satu kesatuan tema yang memuat beberapa pelajaran.
\end{abstract}

Permasalahan yang muncul pada pembelajaran tematik yaitu sebagian siswa menganggap pembelajaran tematik sulit dipahami karena sistem pembelajarannya yang berbasis tema yang memuat beberapa pembelajaran dalam 1 pembelajaran, dengan materi yang terlalu banyak siswa sering mengalami kesulitan, bosan, dan jenuh saat mengikuti pembelajaran dikelas sehingga aktivitas siswa rendah dan dapat mempengaruhi keaktifan dan hasil belajar siswa.

Untuk lebih meningkatkan mutu pendidikan dalam kegiatan pembelajaran yang semula membuat siswa pasif dikelas (teacher centered) menjadi siswa lebih aktif didalam kelas (student centered) dalam pembelajaran Student Centered siswa dituntut untuk selalu aktif dalam pembelajaran. Guru sebagai pendidik harus mampu menciptakan pembelajaran yang baik dalam rangka membantu siswa dalam mengembangkan potensi yang dimilikinya. Keaktifan siswa merupakan hal penting dan 
perlu diperhatikan oleh guru agar proses pembelajaran yang ditempuh benar-benar meningkatkan hasil belajar siswa, khususnya dalam pembelajaran di kelas.

Keaktifan siswa dikelas dapat berkembang dengan baik jika siswa paham mengenai materi pelajaran yang diajarkan oleh guru. Guru harus memikirkan dan membuat perencanaan secara seksama dalam meningkatkan kemampuan belajar siswa dan memperbaiki kualitas mengajarnya.

Faktor penyebab yang dipengaruhi oleh guru adalah kurang melibatkan siswa untuk berperan aktif dalam kegiatan pembelajaran, guru hanya menggunakan metode ceramah, guru tidak menggunakan metode variatif yang sesuai dengan materi yang dipelajari saat kegiatan pembelajaran, guru tidak menggunakan media pembelajaran yang tepat saat proses pembelajaran berlangsung. Masalah lainnya, ketika pembelajaran banyak siswa yang tidak kondusif saat mengikuti pembelajaran di kelas sehingga menganggu konsentrasi siswa lainnya yang akhirnya dapat menurunkan keaktifan dan mempengaruhi hasil belajar siswa, masih banyak siswa yang memiliki nilai dibawah KKM yang disebabkan oleh faktor-faktor tersebut.

Berdasarkan hasil observasi data di kelas IV SDN Komplek Karang Taruna Sari pada tanggal 28 maret 2017 Pembelajaran Tematik di dalam subtema manfaat makanan sehat dan bergizi pembelajaran 5 dengan ketentuan nilai KKM 75 ditemukan beberapa siswa yang memilkiki nilai dibawah KKM, diperoleh data berikut:

Tabel 1 Data Nilai Kelas 4 SDN Komplek Karang Taruna Sari

\begin{tabular}{|c|c|c|c|}
\hline No & Siswa & $\begin{array}{c}\text { Di atas } \\
\text { KKM }\end{array}$ & $\begin{array}{c}\text { Di bawah } \\
\text { KKM }\end{array}$ \\
\hline 1. & $\begin{array}{c}\text { Peremp } \\
\text { uan }\end{array}$ & 5 & 12 \\
\hline 2. & Laki-laki & 4 & 9 \\
\hline \multicolumn{2}{|c|}{ Jumlah Siswa } & 9 & 21 \\
\hline
\end{tabular}

Faktor-faktor yang mempengaruhi keaktifan dan hasil belajar siswa tersebut menuntut guru agar menjadi guru yang profesional, guru yang profesional 
adalah guru yang harus memilki beberapa kompetensi. Hal ini dijelaskan Dalam Undang-Undang Guru No.14 Tahun 2005 pasal 10 ayat 1 menjelaskan bahwa kompetensi guru sebagaimana dimaksud dalam pasal 8 meliputi kompetensi pedagogik, kompetensi kepribadian, kompetensi sosial, dan kompetensi profesional yang diperoleh melalui pendidikan profesi.

Berdasarkan hasil pemikiran penulis dengan melihat faktorfaktor masalah yang terjadi pada siswa seperti pembelajaran yang kurang interaktif, siswa yang kurang kondusif dalam mengikuti pembelajaran di kelas, siswa yang pasif, penggunaan metode atau model pembelajaran yang kurang tepat, hal-hal tersebut telah mempengaruhi keaktifan dan hasil belajar siswa.

Maka solusi alternatif yang digunakan untuk menyelesaikan permasalahan yang timbul dalam pembelajaran tematik yaitu dengan menggunakan model pembelajaran Cooperatif Learning tipe Team Accelerated Intruction.
Team Accelerated Intruction atau percepatan pengajaran adalah salah satu jenis pembelajaran kooperatif (Cooperatif Learning) yang awalnya bernama Team Assisted Individualization atau bantuan individual dalam kelompok (Slavin, 2008, hlm.187).

Model pembelajaran Cooperatif Learning tipe Team Accelerated Intruction merupakan srategi pembelajaran yang berpusat pada siswa (Student Centered). Menurut Robert Slavin (dalam Miftahul, 2013, hlm.200) Team Accelerated Intruction merupakan sebuah program pedagogik yang berusaha mengadaptasikan pembelajaran dengan perbedaan individual siswa secara akademik.

Melalui penelitian ini dengan diterapkannya model cooperative learning tipe team accelerated intruction subtema manfaat makanan dan bergizi pada siswa kelas IV SDN Komplek Karang Taruna Sari dapat mengatasi masalah-masalah dalam pembelajaran yang mempengaruhi keaktifan dan hasil belajar siswa, 
serta terjadinya umpan balik yang baik antara siswa dan guru sehingga tercapainya pengetahuan kognitif, afektif dan psikomotor yang diharapkan sesuai dengan $\mathrm{KI}$ yang telah dirumuskan dalam buku guru yaitu (1) Menerima, menjalankan dan menghargai ajaran agama yang dianutnya, (2) Menunjukkan perilaku jujur, disiplim, tanggungjawab, santun, peduli, dan percaya diri dalam berinteraksi dengan keluarga, teman, guru dan tetangganya, (3) Memahami pengetahuan faktual dengan cara mengamati dan menanya berdasarkan rasa ingin tahu tentang dirinya, makhluk hidup ciptaan Tuhan dan kegiatannya, dan benda-benda yang dijumpai di rumah, di sekolah dan tempat bermain,

Menyajikan pengetahuan faktual dalam bahasa yang jelas, sistematis dan logis, dalam karya yang estetis, dalam gerakan yang mencerminkan anak sehat, dan dalam tindakan yang mencerminkan perilaku anak beriman dan berakhlak mulia.

Oleh karena itu saya sebagai peneliti kan mengambil judul
Perapan Model Cooperative Tipe Team Accelerated Intruction (TAI) Untuk Meningkatkan Keaktifan dan Hasil Belajar Peseta Didik Dalam Pembelajaran Tematik (Penelitian Tindakan Kelas pada Tema Indahnya Kebersamaan, Subtema Keberagaman Budaya Bangsaku di Kelas IV Sekolah Dasar Negeri Komplek Karang Taruna Sari Bandung).

\section{B. LANDASAN TEORI}

1. Model Cooperative Learning Tipe Team Accelerated Intruction (TAl)

a. Definisi Model Cooperative Learning Tipe Team Accelerated Intruction (TAI)

Huda (2014, hlm.125) mengemukakan bahwa model pembelajaran TAl, siswa dikelompokkan berdasarkan kemampuannya yang beragam. Masing-masing kelompok terdiri dari 4 siswa dan ditugaskan untuk menyelesaikan materi pembelajaran atau PR tertentu.

Shoimin (2014, hlm.199) mengemukakan bahwa model pembelajaran Cooperative tipe 
TAl merupakan

model

pembelajaran kooperatif yang

memadukan antara kemampuan

individu yang heterogen dengan kemampuan siswa secara berkelompok. Dalam proses belajarnya, siswa dalam satu kelas dipecah menjadi beberapa kelompok dengan anggota 4-5 orang, setiap kelompok haruslah heterogen yang terdiri dari lakilaki dan perempuan, berasal dari berbagai suku, memiliki kemampuan tinggi, sedang, dan rendah.

Slavin (2015, hlm.187) mengemukakan bahwa model pembelajaran TAI mengadaprasi pengajaran terhadap perbedaan individu berkaitan dengan kemampuan siswa maupun pencapaian prestasi siswa.

Estiningsih (dalam jurnal 2015, hlm.02) mengemukakan bahwa model pembelajaran Cooperative Learning Tipe Team Accelerated Intruction adalah mengelompokkan siswa ke dalam kelompok kecil (4-5 siswa) yang dipimpin oleh seorang ketua (seorang

yangmempunyai pengetahuan lebih dibanding dengan anggota kelompok lainnya). http://jurnal.fkip.uns.ac.id/ index.php/pgsdkebumen/article/vie $w / 1763$

Astrinisngsih (dalam jurnal 2015, hlm.03) mengemukakan bahwa model pembelajaran Team Accelerated Intruction (TAI) adalah salah satu model pembelajaran yang menekankan pentingnya lingkungan alamiah itu diciptakan dalam proses belajar agar kelas lebih hidup dan bermakna karena siswa mengalami sendiri apa yang dipelajarinya, model pembelajaran TAI merupakan model pembelajaran yang memungkinkan siswa untuk menguatkan, memperluas dan menerapkan pengetahuan dan keterampilan akademik mereka dalam berbagai macam tangtangan kehidupan baik di sekolah maupun diluar sekolah. http://ejournal.

undiksha.ac.id/index.php/JJPGSD/ article/view/2327

Dari pendapat para ahli tersebut maka dapat disimpulkan bahwa dalam pembelajaran 
Cooperative terdapat beberapa variasi model yang diterapkan yaitu salah satunya model pembelajaran Cooperative. Model Cooperative Tipe Team Accelerated Intruction (TAI). Model Cooperative Tipe Team Accelerated Intruction (TAI) adalah salah satu pembelajaran yang dapat mengkondisikan siswa dalam suatu lingkungan belajar yang nyaman yaitu belajar kelompok dengan dibantu oleh salah satu siswa pandai dalam anggota kelompok secara individual, saling tukar jawaban, saling berbagi sehingga terjadi diskusi kelompok, tetapi siswa tetap belajar sesuai dengan kecepatan dan kemampuannya masing-masing melalui proses internalisasi. Pembelajaran kooperatif tipe TAI merupakan model pembelajaran kooperatif yang memadukan antara kemampuan individu yang heterogen dengan kemampuan siswa secara berkelompok. Dalam proses belajarnya, siswa dalam satu kelas dipecah menjadi beberapa kelompok dengan anggota 4-5 orang, setiap kelompok haruslah heterogen yang terdiri dari laki-laki dan perempuan, berasal dari berbagai suku, memiliki kemampuan tinggi, sedang, dan rendah.

\section{b. Ciri-ciri Model Cooperative} Learning Tipe Team

\section{Accelerated Intruction (TAl)}

Sutriningsih (dalam jurnal, 2014, hlm.08) mengemukakan bahwa ciri-ciri model pembelajran Cooperative Learning tipe TAI adalah:

1) Setiap siswa secara individual mempelajari materi pembelajaran yang sudah dipersiapkan oleh guru.

2) Hasil belajar individual dibawa ke kelompok-kelompok untuk didiskusikan dan dibahas oleh anggota kelompok.

3) Semua anggota kelompok bertanggung jawab atas keseluruhan jawaban sebagai tanggung jawab bersama.

4) Menitik beratkan pada keaktifan siswa.

http://ejournal.stkipmpringsewuIpg.ac.id/index.php/edumath/arti cle/view/81 
Wulandari (dalam jurnal 2015, hlm.04) mengemukakan bahwa ciri-ciri model pembelajaran Cooperative Learning tipe TAl yaitu:

1) Setiap siswa secara individual belajar materi pembelajaran yang sudah dipersiapkan oleh guru.

2) Hasil belajar individual dibawa ke kelompok-kelompok untuk didiskusikan dan saling dibahas oleh anggota kelompok, dan semua anggota kelompok bertanggung jawab atas keseluruhan jawaban sebagai tanggung jawab bersama.

3) Model pembelajaran kooperatif tipe TAI adalah model pembelajaran kooperatif yang memadukan antara kemampuan individu yang heterogen dengan kemampuan siswa secara berkelompok. http://repository.uksw.edu/bitstre am/123456789/1881/3/T1_2020 08068BAB\%20II.pdf

Dari pendapat tersebut maka dapat disimpulkan bahwa ciri-ciri dari model Cooverative Learning Tipe Team Accelerated Intruction adalah setiap siswa secara individual belajar materi pembelajaran yang sudah dipersiapkan oleh guru, hasil belajar individual dibawa ke kelompok-kelompok untuk didiskusikan dan saling dibahas oleh anggota kelompok, dan semua anggota kelompok bertanggung jawab atas keseluruhan jawaban sebagai tanggung jawab bersama, karena dalam model TAI ini mengutamakan keberhasilan kelompok dibandingkan dengan keberhasilan individu. Model pembelajaran Cooperative tipe TAl adalah model pembelajaran yang memadukan antara kemampuan individu yang heterogen (kemampuan yang berbeda-beda).

c. Langkah-langkah Model Cooperative Learning Tipe Team Accelerated Intruction

Nikadek (dalam jurnal 2014, hlm.04) mengemukakan bahwa langkah-langkah dari pembelajaran Cooperative Learning tipe TAI adalah sebagai berikut:

1) Guru memberikan tugas kepada siswa untuk 
mempelajari materi

pembelajaran secara

individual yang sudah

dipersiapkan oleh guru.

2) Guru memberikan kuis secara individual kepada siswa untuk mendapatkan skor dasar atau skor awal.

3) Guru membentuk beberapa kelompok, Setiap kelompok terdiri dari 4-5 siswa dengan kemampuan yang berbedabeda tingkat kemampuan (tinggi, sedang, rendah), jika mungkin anggota kelompok berasal dari ras, budaya, suku yang berbeda serta kesetaraan gender.

4) Hasil belajar siswa secara individual didiskusikan dalam kelompok. Dalam diskusi kelompok, setiap anggota kelompok saling memeriksa jawaban teman satu kelompoknya.

5) Guru memfasilitasi siswa dalam membuat rangkuman, mengarahkan, dan memberikan penegasan pada materi pembelajaran yang telah dipelajari.
6) Guru memberikan kuis kepada siswa secara individual.

7) Guru memberi penghargaan pada kelompok berdasarkan perolehan nilai peningkatan hasil belajar individual dari skor dasar ke skor kuis berikutnya.http://ejournal.undik sha.ac.id/index.php/JJPGSD/a rticle/viewFile/2429/2102

Wahyuning (dalam jurnal 2015, hlm.07) mengemukakan bahwa langkah-langkah dalam model pembelajaran TAI adalah sebagai berikut:

1) Guru menyiapkan materi bahan ajar yang akan diselesaikan oleh kelompok siswa.

2) Guru memberikan pre-test kepada siswa atau melihat ratarata nilai harian siswa agar guru mengetahui kelemahan siswa pada bidang tertentu. (Mengadopsi komponen Placement Test).

3) Guru memberikan materi secara singkat. (Mengadopsi komponen Teaching Group).

4) Guru membentuk kelompok kecil yang heterogen tetapi 
harmonis berdasarkan nilai
ulangan harian siswa, setiap
kelompok $4-5 \quad$ siswa.
(Mengadopsi
Teams).
5etiap kelompok mengerjakan
tugas dari guru berupa LKS
yang telah dirancang sendiri
sebelumnya, dan guru
memberikan bantuan secara
individual bagi
memerlukannya. (Mengadopsi
komponen Team Study).
Dari pendapat diatas dapat disimpulkan bahwa langkahlangkah dalam TAI adalah (1) guru menyiapkan materi bahan ajar yang akan diselesaikan oleh kelompok siswa,

(2) guru memberikan pretest kepada siswa atau melihat rata-rata nilai harian siswa agar guru mengetahui kelemahan siswa pada bidang tertentu, (3) guru memberikan materi secara singkat tujuannya untuk mengarahkan siswa terhadap materi yang akan dipelajari, (4) guru membentuk kelompok kecil yang heterogen setiap kelompok 4-5 siswa (5) setiap kelompok mengerjakan tugas dari guru berupa LKS yang telah dirancang sendiri sebelumnya, (6) guru memberikan bantuan secara individual bagi yang memerlukannya. (7) ketua kelompok melaporkan keberhasilan kelompoknya dengan mempresentasikan, (8) guru memberikan postest untuk dikerjakan secara individu. Selanjutnya guru menetapkan kelompok terbaik sampai kelompok yang kurang berhasil (jika ada) berdasarkan hasil koreksi, kelompok terbaik diberikan penghargaan agar dapat memotivasi kelompok lainnya untuk menjadi kelompok yang lebih baik lagi dalam pembelajaran selanjutnya (mengadopsi komponen Team Score and Team Recognition). Dan langkah yang terakhir adalah guru memberikan tes formatif sesuai dengan kompetensi yang ditentukan,

d. Kekurangan dan Kelebihan Model Cooperative Learning Tipe Team Accelerated Intruction (TAl)

Rahmatikasari (dalam jurnal, 2014 hlm.03) mengemukakan bahwa kekurangan dan kelebihan 
model Cooperative Learning Tipe

Team Accelerated Intruction (TAI) adalah sebagai berikut:

Tabel 2 Kekurangan dan

Kelebihan Model TAl

\begin{tabular}{|c|c|}
\hline Kekurangan & Kelebihan \\
\hline $\begin{array}{l}\text { Siswa yang } \\
\text { kurang } \\
\text { pandai } \\
\text { secara tidak } \\
\text { langsung } \\
\text { menggantung } \\
\text { kan pada } \\
\text { siswa yang } \\
\text { pandai dan } \\
\text { tidak ada } \\
\text { persaingan. } \\
\text { semua siswa } \\
\text { aktif } \\
\text { berpartisipasi } \\
\text { dalam } \\
\text { kelompok }\end{array}$ & $\begin{array}{l}\text { - Membant } \\
\text { u siswa } \\
\text { yang } \\
\text { kesulitan } \\
\text { memaha } \\
\text { mi materi } \\
\text { pelajaran } \\
\text { melalui } \\
\text { pengajara } \\
\text { n teman } \\
\text { sebaya. } \\
\text { Bahwa } \\
\text { model } \\
\text { kooperatif } \\
\text { tipe Team } \\
\text { Accelerat } \\
\text { ed } \\
\text { Intruction } \\
\text { memberik } \\
\text { an } \\
\text { kesempat } \\
\text { an pada } \\
\text { siswa } \\
\text { untuk } \\
\text { saling }\end{array}$ \\
\hline
\end{tabular}

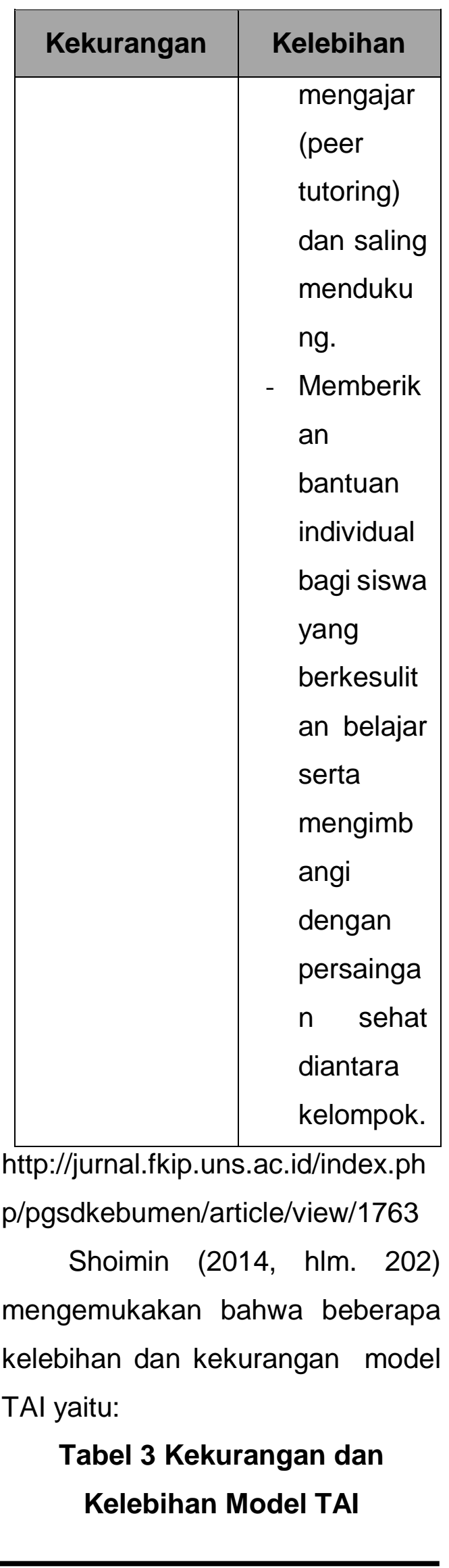




\begin{tabular}{|c|c|}
\hline Kekurangan & Kelebihan \\
\hline 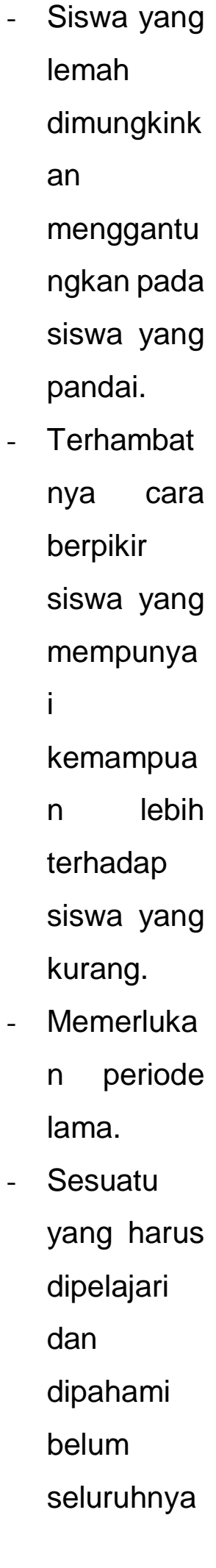 & 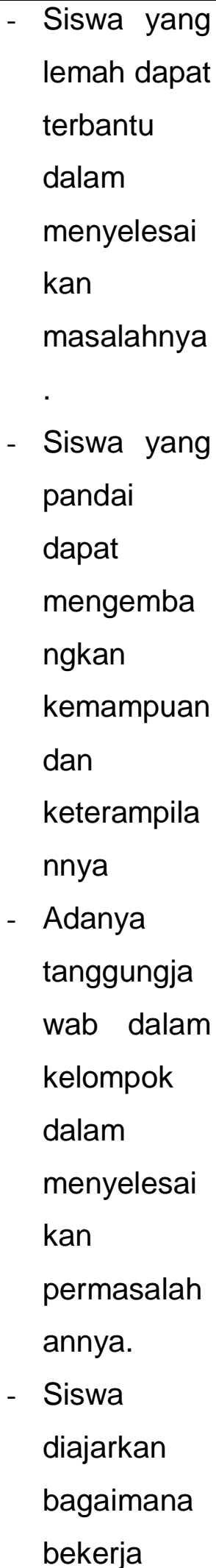 \\
\hline
\end{tabular}

\begin{tabular}{|c|c|}
\hline Kekurangan & Kelebihan \\
\hline dicapai & sama dalam \\
\hline siswa. & suatu \\
\hline - Bila kerja & kelompok. \\
\hline sama tidak & - Mengurangi \\
\hline dapat & kecemasan \\
\hline dilaksanak & - Menghilang \\
\hline an dengan & kan \\
\hline baik, yang & perasaan \\
\hline akan & terisolasi \\
\hline bekerja & dan panik \\
\hline hanyalah & - Menggantik \\
\hline beberapa & an bentuk \\
\hline murid yang & persaingan \\
\hline pintar dan & (competition \\
\hline yang aktif & ) dengan \\
\hline saja. & saling kerja \\
\hline - Siswa yang & sama \\
\hline pintar akan & (cooperatio \\
\hline merasa & n) \\
\hline keberatan & - Melibatkan \\
\hline karena nilai & siswa untuk \\
\hline yang & aktif dalam \\
\hline diperoleh & proses \\
\hline ditentukan & belajar \\
\hline oleh & - Mereka \\
\hline prestasi & dapat \\
\hline atau & berdiskusi, \\
\hline pencapaia & berdebat, \\
\hline $\mathrm{n}$ & atau \\
\hline kelompok. & menyampai \\
\hline
\end{tabular}




\begin{tabular}{|c|c|}
\hline Kekurangan & Kelebihan \\
\hline & $\begin{array}{l}\text { kan } \\
\text { gagasan, } \\
\text { konsep, dan } \\
\text { keahlian } \\
\text { sampai } \\
\text { benar-benar } \\
\text { memahamin } \\
\text { ya. } \\
\text { Mereka } \\
\text { memilki } \\
\text { rasa peduli, } \\
\text { rasa } \\
\text { tanggungja } \\
\text { wab } \\
\text { terhadap } \\
\text { teman lain } \\
\text { dalam } \\
\text { proses } \\
\text { belajarnya. } \\
\text { Mereka } \\
\text { dapat } \\
\text { belajar } \\
\text { menghargai } \\
\text { perbedaan } \\
\text { etnik, } \\
\text { perbedaan } \\
\text { tingkat } \\
\text { kemampuan } \\
\text { dan cacat }\end{array}$ \\
\hline
\end{tabular}

Dari pendapat para ahli tersebut maka dapat disimpulkan bahwa dalam pembelajaran dengan menggunakan model TAI terdapat beberapa kekurangannya yaitu (1) siswa yang kurang pandai secara tidak langsung menggantungkan pada siswa yang pandai, (2) memerlukan waktu yang lebih lama dalam pembelajarannya, (3) sesuatu yang harus dipelajari dan dipahami belum seluruhnya dicapai siswa bila kerja sama tidak dapat dilaksanakan dengan baik, (4) pembelajaran secara berkelompok memiliki kemungkinan pembelajaran didominasi oleh beberapa orang saja yang menyebabkan siswa lainnya menjadi pasif, (5) siswa yang pintar akan merasa keberatan karena nilai yang diperoleh ditentukan oleh prestasi atau pencapaian kelompok. Selain memilki kekurangan model pembelajaran Cooperative Learning Tipe Team Accelerated Intruction (TAI) memiliki kelebihan yaitu (1) siswa diajarkan bagaimana bekerja sama dalam suatu kelompok, (2) siswa 
yang pasif dan memiliki

kemampuan rendah dapat terbantu dengan siswa yang memiliki kemampuan lebih, (3) melibatkan siswa untuk aktif dalam proses belajar mereka dapat berdiskusi, berdebat, atau menyampaikan gagasan, konsep, dan keahlian sampai

benar-benar

memahaminya. (4) Mereka memilki rasa peduli, rasa tanggungjawab terhadap teman lain dalam proses belajarnya, dan mereka dapat belajar menghargai perbedaan etnik, perbedaan tingkat kemampuan, dan cacat fisik.

\section{Keaktifan Belajar}

\section{a. Definisi Keaktifan Belajar}

Sardiman (2012, hlm.98) mengemukakan bahwa keaktifan adalah kegiatan yang bersifat fisik maupun mental, yaitu berbuat dan berfikir sebagai suatu rangkaian yang tidak dapat dipisahkan Belajar yang berhasil harus melalui berbagai macam aktifitas, baik aktifitas fisikmaupun psikis.

Aunurrahman (2012, hlm.119) mengemukakan bahwa keaktifan siswa dalam belajar merupakan persoalan penting dan mendasar yang harus dipahami, dan dikembangkan setiap guru dalam proses pembelajaran. Sehingga keaktifan siswa perlu digali dari potensi-potensinya, yang mereka aktualisasikan melalui aktifitasnya untuk mencapai tujuan pembelajaran.

Hermawan (dalam jurnal Anggraeni 2014, hlm.08) mengemukakan bahwa keaktifan belajar adalah untuk mengkontruksi pengetahuan mereka sendiri, mereka aktif membangun pemahaman atas persoalan atau segala sesuatu yang mereka hadapi dalam kegiatan pembelajaran.http://journal.unnes. ac.id/nju/index.php/kreatif/article/vi ewfile/1681/1887

Rohani (dalam jurnal Aryani, 2014, hlm.03) mengemukakan bahwa keaktifan belajar adalah berbagai aktivitas fisik maupun psikis yang membuat ia bermain ataupun bekerja, ia tidak hanya duduk dan mendengarkan, melihat atau hanya pasif. http://ejournal.unnes.ac.id/nju/inde x.php 
/JJPGSD/article/viewfile/242/9/210

2.

Dari pendapat para ahli tersebut maka dapat disimpulkan bahwa keaktifan belajar merupakan suatu usaha yang dilakukan siswa untuk melaksanakan kegiatan belajar. Keaktifan dapat ditunjukkan dengan keterlibatan siswa dalam mencari atau mendapatkan sebuah informasi dari suatu sumber seperti buku, guru, dan teman lainnya, sehingga siswa diharapkan akan lebih mampu secara penuh menyadari dan menggunakan potensi sumber belajar yang terdapat disekitarnya. Keaktifan belajar siswa dapat dilihat berdasarkan indikator keaktifan siswa yaitu turut serta dalam melaksanakan tugas belajarnya, terlibat dalam pemecahan permasalahan, bertanya kepada siswa lainnya atau kepada guru apabila tidak memahami persoalan yang dihadapinya, berusaha mencari berbagai informasi yang diperlukan untuk pemecahan masalah, melaksanakan diskusi kelompok sesuai dengan petunjuk guru, menilai kemampuan dirinya dan hasil-hasil yang diperolehnya, melatih diri dalam memecahkan soal masalah sejenis dan kesempatan menggunakan atau menerapkan apa yang telah diperolehnya dalam menyelesaikan tugas atau persoalan yang dihadapinya.

\section{b. Faktor-faktor}

yang Mempengaruhi Keaktifan

\section{Belajar}

Muhibbin (2012, hlm.146) mengemukakan bahwa faktor yang mempengaruhi keaktifan belajar peserta didik adalah sebagai berikut:

1) Faktor internal peserta didik, merupakan faktor yang berasal dari dalam diri peserta didik itu sendiri, yang meliputi:

a) aspek fisiologis, yaitu kondisi umum jasmani dan tonus (tegangan otot) yang menandai tingkat kebugaran organ-organ tubuh dan sendi-sendinya, dapat mempengaruhi semangat dan intensitas peserta didik dalam mengikuti pelajaran.

b) aspek psikologis, belajar pada hakikatnya adalah proses psikologis. oleh karena itu, 


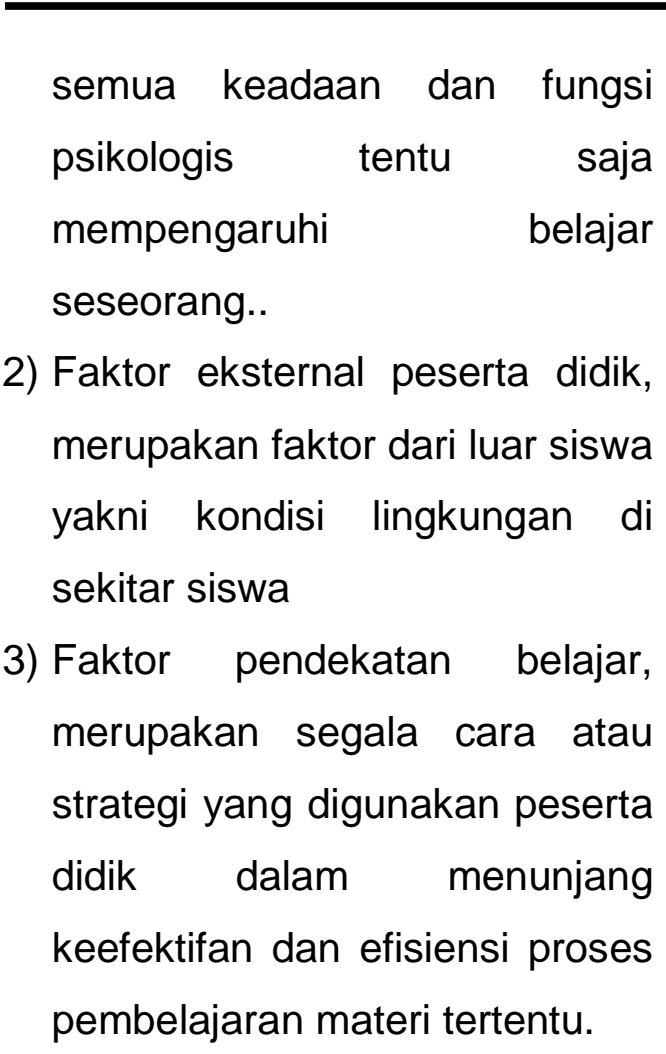

Ahmadi (2012, hlm.78)

mengemukakan bahwa faktor yang mempengaruhi keaktifan belajar peserta didik diklasifikasikan menjadi dua macam, yaitu faktor intern (faktor dari dalam diri manusia itu sendiri) yang meliputi faktor fisiologis dan psikologi, serta faktor ektern (faktor dari luar manusia) yang meliputi faktor sosial dan non sosial.

Gagne dan Briggs (dalam jurnal Kurniawati, 2014, hlm.07) mengemukakan bahwa faktorfaktor yang dapat dilakukan oleh guru untuk menumbuhkan keaktifan peserta didik dalam proses pembelajaran yaitu:

a) Memberikan motivasi atau menarik perhatian peserta didik dalam kegiatan pembelajaran.

b) Menjelaskan tujuan instruksional (kemampuan dasar kepada peserta didik).

c) Mengingatkan kompetensi belajar kepada peserta didik.

d) Memberikan stimulus (masalah, topik dan konsep yang akan dipelajari).

e) Memberi petunjuk kepada peserta didik cara mempelajarinya.

f) Memunculkan aktifitas dan partisipasi peserta didik dalam kegiatan pembelajaran.

g) Memberi umpan balik (feed back)

h) Melakukan tagihan-tagihan terhadap peserta didik peserta didik berupa tes sehingga kemampuan peserta didik selalu terpantau dan terukur.

i) Menyimpulkan setiap materi yang disampaikan diakhir pelajaran.

http://eprints.ums.ac.id/8677/2/A 210060103.pdf 
Menurut Wulandari (dalam jurnal, 2015, hlm.05) keaktifan belajar siswa dipengaruhi oleh faktor fisiologis dan psikologis seperti kecerdasan, motivasi berprestasidan kemampuan kognitif, faktor lingkungan dan faktor instrumental seperti guru, kurikulum, dan model pembelajaran. Semakin tinggi kualitas dari masing-masing faktor tersebut maka semakin tinggi pula keaktifan belajar siswa. http://repository.uksw.edu/bitstrea $\mathrm{m} /$ $123456789 /$ 1881/3/T1_202008068BAB\%20II.p df

Aritohang (dalam jurnal 2016, hlm.11) faktor-faktor yang mempengaruhi keaktifan belajar adalah minat individu merupakan ketertarikan individu terhadap sesuatu. Minat belajar siswa yang tinggimenyebabkan belajar siswa lebih mudah dan cepat, motivasi belajar antara siswa yang satu dengan siswa lainnya tidaklah sama dan faktor lingkungan sosial. http://s3.amazonaws.com/ academia.edu.documents/3590479 9/Hal._11.pdf
Dari pendapat tersebut maka dapat disimpulkan bahwa keaktifan belajar dapat dipengaruhi oleh dua faktor yaitu faktor internal dan faktor eksternal. Faktor internal merupakan faktor yang berasal dari dalam diri siswa, sedangkan faktor eksternal merupakan faktor yang berasal dari luar diri siswa. Faktor yang termasuk faktor internal adalah faktor fisiologis dan psikologis seperti kecerdasan, motivasi berprestasi dan kemampuan kognitif. Sedangkan yang termasuk faktor eksternal adalah faktor lingkungan dan faktor instrumental seperti guru, kurikulum, media pembelajaran, metode pembelajaran, strategi pembelajaran dan model pembelajaran. Semakin tinggi kualitas dari masing-masing faktor tersebut maka semakin tinggi pula keaktifan belajar siswa.

\section{Hasil Belajar}

\section{a. Definisi Hasil Belajar}

Purwanto (2011, hlm.46) mengemukakan bahwa hasil belajar adalah perubahan perilaku peserta didik akibat belajar. Perubahan perilaku disebabkan 


\section{Didaktik : Jurnal Pendidikan Guru Sekolah Dasar, ISSN : 24775673 \\ Sekolah Tinggi Keguruan dan IImu Pendidikan Subang Volume II Nomor 2, Juli 2017}

karena dia mencapai penguasaan

atas sejumlah bahan yang diberikan dalam proses belajar mengajar. Lebih lanjut lagi ia mengatakan bahwa hasil belajar dapat berupa perubahan dalam aspekkognitif, afektif dan psikomotorik.

Nawawi (2013, hlm.06) mengemukakan bahwa hasil belajar adalah keberhasilan murid dalam mempelajari materi pelajaran di sekolah yang dinyatakan dalam bentuk nilai atau skor dari hasil tes mengenai sejumlah pelajaran tertentu.

Sukmadinata

(dalam

Kustawan, 2013, hlm.08) mengemukakan bahwa hasil belajar merupakan realisasi dari kecakapan-kecakapan potensial atau kapasitas yang dimiliki seseorang.

Sudjana (2016, hlm.22) mengemukakan bahwa hasil belajar adalah kemampuankemampuan yang dimiliki siswa setelah ia menerima pengalaman hasil belajarnya.

Ani (dalam jurnal Aritohang, 2016, hlm.10) mengemukakan bahwa hasil belajar merupakan perubahan perilaku yang diperoleh pembelajar setelah mengalami aktivitas belajar. http://s3.amazonaws.com/academi a.edu.documents/35904799/Hal._1 1.pdf

Dari pendapat tersebut maka dapat disimpulkan bahwa hasil belajar adalah perubahan tingkah laku peserta didik karena melalui proses belajar dan pembelajaran, hal tersebut terjadi karena dia telah mencapai penguasaan atas bahan yang telah diberikan oleh guru selama proses pembelajaran berlangsung, hasil belajar meliputi beberapa aspek yaitu aspek kognitif, afektif dan psikomotorik, hasil belajar merupakan kemampuan siswa yang telah diperoleh sesudah melakukan belajar dan pembelajaran selama aktivitas belajar berlangsung.

\section{b. Aspek-aspek Hasil Belajar}

Arikunto (dalam jurnal Nikadek, $2014 \quad$ hlm.11) mengemukakan bahwa aspekaspek dalam hasil belajar yaitu:

1) Cognitive domain

a) Pengetahuan (knowledge) 
Mendefinisikan,

mendeskripsikan, mengidentifikasi, mendaftarkan, menjodohkan, menyebutkan, menyatakan (states), mereproduksi.

b) Pemahaman (comprehension) Mempertahankan, membedakan, menduga (estimates), menerangkan, memperluas, menyimpulkan, menggeneralisasikan, memberikan contoh, menuliskan kembali, memperkirakan.

c) Aplikasi

Mengubah, menghitung, mendemonstrasikan,

memanipulasikan, memodifikasikan, mengoperasikan, meramalkan, menyiapkan, menghasilkan, menghubungkan, menunjukkan, memecahkan, menggunakan.

d) Analisis Memerinci, menyusun diagram, mebedakan, mengidentifikasikan,

mengilustrasikan, menyimpulkan, menunjukkan, menghubungkan, memilih, meisahkan, membagi (subdivides)

e) Sintesis
Mengategorikan,

mengombinasikan, mengarang, menciptakan, membuat desain, menjelaskan, memodifikasikan, mengorganisasikan, menyusun, membuat rencana, mengatur kembali, merekonstruksikan, menghubungkan,

mereorganisasikan, merevisi, menuliskan kembali, menuliskan, menceritakan.

f) Evaluasi

Menilai membandingkan, menyimpulkan, mempertentangkan, mengkritik, mendeskripsikan, membedakan, menerangkan, memutuskan, menafsirkan, menghubungkan, membantu (supports)

b) Affective domain

a) Receiving

Menanyakan, memilih, mendeskripsikan, mengikuti, memberikan ,mengidentifikasikan, menyebutkan, menunjukkkan, memilih, menjawab.

b) Responding

$$
\text { Menjawab, }
$$
membantu, mendiskusikan, menghormat, berbuat, melakukan, membaca, memberikan, menghafal, 
melaporkan,

memilih,

menceritakan, menulis.

c) Valuing

Melengkapi,

menggambarkan, membedakan, menerangkan,

mengikuti,

membentuk, mengudang,

menggabungkan, mengusulkan, membaca, melaporkan, memilih, bekerjasama, mengambil bagian (share), mempelajari.

d) Organization

Mengubah,

mengatur

menggabungkan, membandingkan, melengkapi, mempertahankan, menerangkan,

menggeneralisasikan,

mengidentifikasikan,

mengitegrasikan, memodifikasikan, mengorganisir, menyiapkan, menghubungkan, mensintesiskan.

e) Characterization by value or value complex

Membedakan, menerapkan, mengusulkan, memperagakan, mempengaruhi, mendengarkan, memodifikasikan,

mempertunjukkan, menanyakan, merevisi, melayani, memecahkan, menggunakan.

c) Psycomotor domain a) Muscular or motor skills

Mempertontonkan gerak, menunjukkan hasil, (pekerjaan tangan), melompat, menggerakkan, menampilkan.

b) Manipulations of material or objects

mereparasi, menyusun, membersihkan, menggeser, memindahkan, membentuk.

c) Neuromuscular coordination

Mengamati, menerapkan, menghubungkan, menggandeng, memadukan, memasang, memotong, menarik, menggunakan. http://ejournal. undiksha.ac. id/index.php/JJPGSD/article/viewFi le/2429/2102

Sedangkan Sudjana (2016, hlm.22) mengemukakan bahwa dalam hasil belajar terdapat 3 aspek yaitu:

1) Ranah kognitif

Berkenaan hasil belajar intelektual yang terdiri dari enam aspek, yaitu pengetahuan atau ingatan, pemahaman, aplikasi, analisis, sintesis, dan evaluasi, kedua aspek pertama disebut kognitif tingkat rendah dan keempat 


\section{Didaktik : Jurnal Pendidikan Guru Sekolah Dasar, ISSN : 24775673 \\ Sekolah Tinggi Keguruan dan IImu Pendidikan Subang Volume II Nomor 2, Juli 2017}

aspek berikutnya termasuk kognitif tingkat tinggi.

2) Ranah afektif

Berkenaan dengan sikap yang terdiri dari lima aspek yaitu penerimaan, jawaban atau reaksi, penilaian, organisasi, dan internalisasi. Beberapa ahli mengatakan bahwa sikap seseorang dapat diramalkan perubahannya, bila seseorang telah memilki penugasan koginitif tingkat tinggi. Penilaian hasil belajar afektif kurang mendapat perhatian dari guru. Para guru lebih banyak menilai ranah kognitif sematamata. Tipe hasil belajar afektif tampak pada siswa dalam berbagai tingkah laku seperti perhatiannya terhadap pelajaran, disiplin, motivasi belajar, dan hubungan sosial.

3) Ranah psikomotor

Berkenaan dengan hasil belajar keterampilan dan kemampuan bertindak, ada enam aspek psikomotor yaitu gerakan refleks, keterampilan gerakan dasar, kemampuan perspektual,keharmonisan atau kompleks, dan gerakan ekpresif dan interpretatif.

Dari pendapat para ahli tersebut maka dapat disimpulkan bahwa penilaian hasil belajar menginsyaratkan hasil belajar sebagai program atau objek yang menjadi sasaran penelitian. Hasil belajar sebagai objek penelitian pada hakikatnya menilai penguasaan siswa terhadap tujuan-tujuan instruksional. Hal ini adalah karena isi rumusan tujuan instruksional menggambarkan hasil belajar yang harus dikuasai siswa berupa kemampuan-kemampuan siswa setelah menerima atau menyelesaikan pengalaman belajarnya. Aspek-aspek dalam hasil belajar meliputi ranah koginitif berkenaan hasil belajar intelektual yang terdiri dari enam aspek, yaitu pengetahuan atau ingatan, pemahaman, aplikasi, analisis, sintesis, dan evaluasi, kedua aspek pertama disebut kognitif tingkat rendah dan keempat aspek berikutnya termasuk kognitif tingkat tinggi. Ranah afektif berkenaan dengan sikap yang terdiri dari lima aspek yaitu penerimaan, jawaban 
atau reaksi, penilaian, organisasi, dan internalisasi dan yang terakhir adalah ranah psikomotor berkenaan dengan hasil belajar keterampilan dan kemampuan bertindak, ada enam aspek psikomotor yaitu gerakan refleks, keterampilan gerakan dasar, kemampuan

perspektual,keharmonisan atau kompleks, dan gerakan ekpresif dan interpretatif.

\section{METODE PENELITIAN}

Metode penelitian pada dasarnya merupakan cara ilmiah untuk mengumpulkan data dengan tujuan dan kegunaan tertentu. Cara ilmiah berarti kegiatan penelitian itu didasarkan pada ciri-ciri keilmuan yaitu rasional, empiris dan sistematis.

Metode yang digunakan dalam penelitian ini adalah Classroom Action Research atau Penelitian Tindakan Kelas (PTK). Sering kali berbagai permasalahan muncul dari praktek sehari-hari yang dirasakan langsung oleh guru dan siswa didalam kelas. Masalah yang dimaksud adalah masalah yang terkait dengan proses pembelajaran.

Sugiyono (2011, hlm. 06) menyatakan bahwa metode penelitian adalah cara-cara ilmiah untuk mendapatkan data yang valid, dengan tujuan dapat ditemukan, dikembangkan dan dibuktikan, suatu pengetahuan tertentu sehingga pada gilirannya dapat digunakan untuk memahami, memecahkan, dan mengantisipasi masalah.

Kemis dan Taggart (dalam wibawa, 2014, hlm.02) mengemukakan bahwa penelitian tindakan adalah suatu bentuk penelitian reflektif diri kolektif yang dilakukan oleh pesertapesertanya dalam situasi sosial untuk meningkatkan penalaran dan keadilan praktik pendidikan dan praktik sosial mereka, serta pemahaman mereka terhadap praktik-praktik itu dan terhadap situasi tempat dilakukan praktikpraktik tersebut.

Wardani (2014, hlm.03) menegmukakan bahwa penelitian tindakan kelas merupakan satu penelitian pula, yang dengan 
sendirinya mempunyai berbagai aturan dan langkah yang harus diikuti. Penelitian tindakan kelas merupakan terjemahan dari Classroom Action Research, yaitu satu Action Research yang dilakukan di kelas.

Wardani (2014, hlm.04) mengemukakan bahwa ide pokok dari penelitian tindakan kelas adalah sebagai berikut:

1) Penelitian tindakan adalah satu bentuk inkuiri atau penyelidikan yang dilakukan melalui refleksi diri.

2) Penelitian tindakan dilakukan oleh peserta yang terlibat dalam situasi yang diteliti, seperti guru, siswa, atau kepala sekolah.

3) Penelitian tindakan dilakukan dalam situasi sosial, termasuk situasi pendidikan.

4) Tujuan penelitian tindakan adalah memperbaiki dasar pemikiran dan kepantasan dari praktik-praktik, pemahaman terhadap praktik tersebut, serta situasi atau lembaga tempat praktik tersebut dilaksanakan.
Dapat disimpulkan dari uraian pendapat para ahli tentang pengertian PTK diatas, bahwa Penelitian Tindakan Kelas merupakan langkah nyata yang bisa dilakukan oleh guru atau peneliti lain menemukan solusi terhadap masalah yang ada didalam kelas dalam proses pembelajaran.

Peneliti menggunakan metode ini dengan alasan karena metode penelitian ini sangat tepat jika digunakan untuk meneyelesaikan masalah yang timbul di dalam kelas, karena (PTK) sangat relevan dengan kebutuhan mengatasi maslaah dikelas. Langkah-langkah PTK secara garis besar adalah perencanaan, pelaksanaan, pengamatan dan refleksi.

\section{PEMBAHASAN}

Penelitian ini dilakukan dengan tujuan meningkatkan keaktifan dan hasil belajar siswa dengan menerapkan model Cooperative Learning tipe Team Accelerated Intruction (TAI) di kelas IV SDN Komplek Karang Taruna 
Sari. Dengan penerapan model Cooperative Learning tipe Team Accelerated Intruction

diharapkan akan meningkatkan kekatifan dan hasil belajar siswa. Demi meningkatkan kualitas pembelajaran tersebut maka akan dibahas kinerja guru dan output belajar siswa.

1) Penerapan

Pelaksanaan (RPP)

\section{Rencana}

Pelaksanaan

Pembelajaran (RPP) dapat meningkatkan kekatifan dan hasil belajar pada pembelajaran subtema keberagaman budaya bangsaku dengan data yang telah dikumpulkan melalui rubrik penilaian RPP yang dinilai oleh observer (wali kelas IV). Hal ini dilakukan untuk mengukur kualitas RPP dari setiap komponennya.

Berdasarkan hasil observasi yang peneliti himpun mulai dari siklus pertama sampai siklus III, menunjukkan bahwa perencanaan pembelajaran berupa dokumen RPP mengalami perbaikan dan peningkatan, peningkatan yang dilihat oleh observer adalah pemilihan materi ajar, kesesuaian langkah pembelajaran dengan indikator, pemilihan sumber, bahan, dan media pembelajaran. Perbaikan yang dilihat observer adalah pengorganisasian materi ajar. Pada siklus I perencanaan pembelajaran mendapatkan persentase sebesar 76,05\% dengan nilai akhir sebesar 3,06 dan memperoleh kriteria baik. Perencanaan pada siklus I dirasa kurang baik sehingga dilakukan refleksi. Dalam kegiatan refleksi didapatkan bahwa persiapan bahan ajar kurang sehingga diperbaiki dalam siklus II dan mendapatkan persentase keberhasilan sebesar 86,05\% dengan nilai akhir 3,46 dan mendapat kriteria baik. Sebelum melaksanakan siklus III dilakukan refleksi, pada kegiatan refleksi ditemukan bahwa penggunaan media pembelajaran pada siklus II masih kurang sehingga diperbaiki pada siklus III dan mendapatkan persentase keberhasilan 93,25\% dengan perolehan nilai 3,73 dan mendapatkan kriteria sangat baik. 
Langkah-langkah

pembelajaran dalam Rencana

Pelaksanaan Pembelajaran (RPP) yang sesuai dengan model yang digunakan yaitu Model Cooperative Learning Tipe Team Accelerated Intruction.

Nikadek (dalam jurnal 2014, hlm.04) mengemukakan bahwa langkah-langkah dari pembelajaran Cooperative Learning tipe TAl adalah sebagai berikut:

a) Guru memberikan tugas kepada siswa untuk mempelajari materi pembelajaran secara individual yang sudah dipersiapkan oleh guru.

b) Guru memberikan kuis secara individual kepada siswa untuk mendapatkan skor dasar atau skor awal.

c) Guru membentuk beberapa kelompok, Setiap kelompok terdiri dari 4-5 siswa dengan kemampuan yang berbedabeda tingkat kemampuan (tinggi, sedang, rendah), jika mungkin anggota kelompok berasal dari ras, budaya, suku yang berbeda serta kesetaraan gender.

d) Hasil belajar siswa secara individual didiskusikan dalam kelompok. Dalam diskusi kelompok, setiap anggota kelompok saling memeriksa jawaban teman satu kelompoknya.

e) Guru memfasilitasi siswa dalam membuat rangkuman, mengarahkan, dan memberikan penegasan pada materi pembelajaran yang telah dipelajari.

f) Guru memberikan kuis kepada siswa secara individual.

g) Guru memberi penghargaan pada kelompok berdasarkan perolehan nilai peningkatan hasil belajar individual dari skor dasar ke skor kuis berikutnya.

Data peningkatan Rencana Pelaksanaan Pembelajaran (RPP) pada siklus I, siklus II dan siklus III yang peneliti susun dengan menggunakan model pembelajaran Cooperative Learning Tipe Team Accelerated Intruction (TAl) di kelas IV SDN Komplek Karang Taruna 
Sari dapat dilihat pada Tabel 3 dibawah ini:

Tabel 3 Rekapitulasi Hasil

Observasi Rencana Pelaksanaan

Pembelajaran (RPP)

\begin{tabular}{|c|c|c|c|c|}
\hline $\begin{array}{c}\text { N } \\
\text { o. }\end{array}$ & $\begin{array}{c}\text { Sikl } \\
\text { us }\end{array}$ & $\begin{array}{c}\text { Persenta } \\
\text { se }\end{array}$ & $\begin{array}{c}\text { Nila } \\
\text { ikh } \\
\text { ir }\end{array}$ & $\begin{array}{c}\text { Kriter } \\
\text { ia }\end{array}$ \\
\hline 1. & $\begin{array}{c}\text { Siklu } \\
\text { s I }\end{array}$ & $76,05 \%$ & 3,06 & Baik \\
\hline 2. & $\begin{array}{c}\text { Siklu } \\
\text { s II }\end{array}$ & $86,05 \%$ & 3,46 & Baik \\
\hline 3. & $\begin{array}{c}\text { Siklu } \\
\text { s III }\end{array}$ & $93,25 \%$ & 3,73 & $\begin{array}{c}\text { Sang } \\
\text { at } \\
\text { Baik }\end{array}$ \\
\hline
\end{tabular}

Sumber: Hasil observasi

Rencana

Pelaksanaan

Pembelajaran (RPP) pada siklus I, siklusll dan siklus III.

Berdasarkan hasil Rencana Pelaksanaan Pembelajaran (RPP) diatas dapat disimpulkan bahwa penggunaan model Cooperative Learning tipe Team Accelerated Intruction

(TAl) dapat meningkatkan kekatifan dan hasil belajar siswa pada subtema keberagaman budaya bangsaku di kelas IV SDN Komplek Karang Taruna Sari Kota Bandung.

2) Pelaksanaan Pembelajaran Guru
Hasil dari observasi siklus I, siklus II dan siklus III menunjukan peningkatan pelaksanaan pembelajaran yang dilakukan oleh guru dengan menerapkan model pembelajaran Cooperative Learning tipe Team Accelerated Intruction (TAI) subtema keberagaman budaya bangsaku di kelas IV SDN Komplek Karang Taruna Sari. Dalam pelaksanaan pembelajaran siklus I dilakukan kegiatan apresepsi dan penguasaan kelas mendapat nilai kurang. Pada pelaksanaan siklus II pelaksanaan pembelajaran mengalami peningkatan namun masih ada yang harus ditingkatkan yaitu pengkondisian kelas dalam kelompok.

Kekurangan tersebut di perbaiki pada siklus III dalam pelaksanaan pembelajaran siklus III mengalami peningkatan dibandingkan dengan siklus sebelumnya.

Pada siklus I pelaksanaan pembelajaran yang dilakukan oleh guru masih banyak perbaikan. Dari hasil observasi yang dilakukan oleh observer menunjukkan bahwa pelaksanaan pembelajaran oleh 
guru mendapatkan persentase keberhasilan sebesar 77,25\% dengan nilai akhir 3,09 dan memperoleh kriteria baik. Pada siklus II pelaksanaan pembelajaran mengalami peningkatan. Data yang di dapatkan pada siklus II memperoleh persentase keberhasilan sebesar $84 \%$ dengan nilai akhir 3,36 dan mendapatkan kriteria baik, kekurangan pada siklus II diperbaiki pada siklus III. Dalam pelaksanaan pembelajaran di siklus III mengalami peningkatan dibandingkan dengan pelaksanaan pada siklus sebelumnya, siklus III memperoleh persentase keberhasilan sebesar $92 \%$ dengan nilai akhir 3,68 dan mendapatkan kriteia sangat baik.

Wahyuning (dalam jurnal 2015, hlm.07) mengemukakan bahwa langkah-langkah dalam model pembelajaran TAI adalah sebagai berikut:

a) Guru menyiapkan materi bahan ajar yang akan diselesaikan oleh kelompok siswa.

b) Guru memberikan pre-test kepada siswa atau melihat ratarata nilai harian siswa agar guru mengetahui kelemahan siswa pada bidang tertentu. (Mengadopsi komponen Placement Test).

c) Guru memberikan materi secara singkat. (Mengadopsi komponen Teaching Group).

d) Guru membentuk kelompok kecil yang heterogen tetapi harmonis berdasarkan nilai ulangan harian siswa, setiap kelompok 4-5 siswa. (Mengadopsi komponen Teams).

e) Setiap kelompok mengerjakan tugas dari guru berupa LKS yang telah dirancang sendiri sebelumnya, dan guru memberikan bantuan secara individual bagi yang memerlukannya. (Mengadopsi komponen Team Study).

Data pelaksanaan pembelajaran pada siklus I, siklus II dan siklus III yang peneliti susun dengan menggunakan model Cooperative Learning tipe Team Accelerated Intruction (TAl) dalam pembelajaran subtema keberagaman budaya bangsaku di kelas IV SDN Komplek Karang Taruna Sari dapat dilihat pada tabel di bawah ini: 
Tabel 4 Rekapitulasi Hasil Observa si Pelaksanaan Pembelajaran

\begin{tabular}{|c|c|c|c|c|}
\hline $\begin{array}{c}\text { N } \\
\text { o. }\end{array}$ & $\begin{array}{c}\text { Sikl } \\
\text { us }\end{array}$ & $\begin{array}{c}\text { Presenta } \\
\text { se }\end{array}$ & $\begin{array}{c}\text { Nila } \\
\text { i } \\
\text { Akh } \\
\text { ir }\end{array}$ & $\begin{array}{c}\text { Kriter } \\
\text { ia }\end{array}$ \\
\hline 1. & $\begin{array}{c}\text { Siklu } \\
\text { s I }\end{array}$ & $77,25 \%$ & 3,09 & Baik \\
\hline 2. & $\begin{array}{c}\text { Siklu } \\
\text { s II }\end{array}$ & $84 \%$ & 3,36 & Baik \\
\hline 3. & $\begin{array}{c}\text { Siklu } \\
\text { s III }\end{array}$ & $92 \%$ & 3,68 & $\begin{array}{c}\text { Sang } \\
\text { at } \\
\text { Baik }\end{array}$ \\
\hline \multicolumn{2}{|l}{ Sumber: } & Hasil & \multicolumn{3}{|c|}{ observasi }
\end{tabular}

pelaksanaan pembelajaran Siklus I, siklus II dan siklus III.

Dari hasil penelitian tersebut terbukti bahwa kemampuan guru dalam menerapkan model Cooperative Learning Tipe Team Accelerated Intruction mengalami peningkatan dari mulai siklus I dengan nilai 3,09 mengalami peningkatan pada siklus II yaitu 3,36 dan siklus III dengan perolehan nilai 3,68.

\section{3) Peningkatan Keaktifan Siswa}

Data yang didapatkan dari hasil observasi keaktifan siswa pada aspek yang diamati yaitu keberanian, berpartisipasi, keaktifan belajar, dan percaya diri. Pada siklus I aspek-aspek tersebut mendapat nilai kurang sehingga diperbaki pada siklus II, pada siklus II menglami peningkatan namun masih ada beberapa siswa yang belum mengalami peningkatan maka diperbaiki pada siklus III, pada siklus III aspek-aspek yang diamati observer mengalami peningkatan keberhasilan.

Keaktifan siswa dihitung berdasarkan jumlah siswa yang tuntas dan mencapai KKM pada suatu kelas. Dari jumlah siswa sebanyak 30 orang, pada siklus I jumlah siswa yang tuntas mencapai KKM sebesar $20 \%$ dengan jumlah siswa 6 orang. Pada siklus II mengalami peningkatan siswa yang tuntas mencapai nilai KKM yaitu dengan persentase sebesar 46,66\% dengan jumlah siswa 14 orang. Pada siklus III mengalami peningkatan yaitu dengan persentase sebesar $86,66 \%$ atau 26orang.

Gagne dan Briggs (dalam jurnal Kurniawati, 2014, hlm.07) mengemukakan bahwa faktorfaktor yang dapat dilakukan oleh guru untuk menumbuhkan keaktifan peserta didik dalam proses pembelajaran yaitu:

a) Memberikan motivasi atau menarik perhatian peserta didik dalam kegiatan pembelajaran. 
b) Menjelaskan tujuan instruksional (kemampuan dasar kepada peserta didik).

c) Mengingatkan kompetensi belajar kepada peserta didik.

d) Memberikan stimulus (masalah, topik dan konsep yang akan dipelajari).

e) Memberi petunjuk kepada peserta didik cara mempelajarinya.

f) Memunculkan aktifitas dan partisipasi peserta didik dalam kegiatan pembelajaran.

g) Memberi umpan balik (feed back)

h) Melakukan tagihan-tagihan terhadap peserta didik peserta didik berupa tes sehingga kemampuan peserta didik selalu terpantau dan terukur.

i) Menyimpulkan setiap materi yang disampaikan diakhir pelajaran.

http://eprints.ums.ac.id/8677/2/A 210060103.pdf

Data peningkatan aktivitas keaktifan siswa pada siklus I, siklus II, dan siklus III yang peneliti susun dengan menggunakan model Cooperative Learning Tipe Team
Accelerated Intruction (TAI) pada subtema keberagaman budaya bangsaku di kelas IV SDN Komplek Karang Taruna Sari dapat dilihat pada tabel berikut:

\section{Diagram 1 Rekapitulasi Aktifitas Keaktifan Siswa}

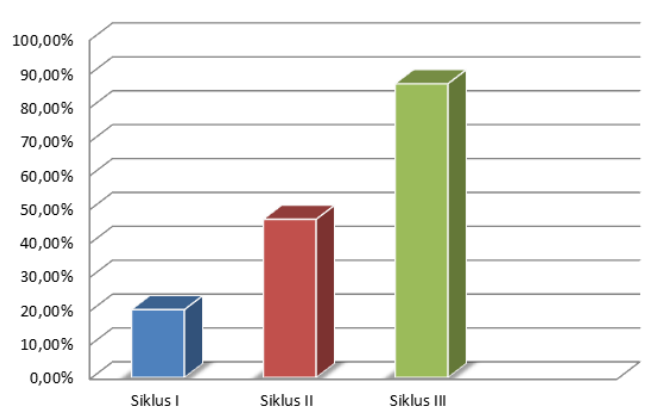

Dari data diatas membuktikan bahwa dengan menggunakan model pembelajaran Cooperative Learning Tipe Team Accelerated Intruction (TAl) dapat meningkatkan keaktifan belajar siswa.

\section{4) Pembahasan Peningkatan Hasil Belajar}

Data peningkatan keaktifan belajar berbanding lurus dengan meningkatnya hasil belajar siswa. Sehingga diharapkan dengan kelebihan Cooperative Learning Tipe Team Accelerated Intruction (TAI) akan meningkatkan hasil belajar siswa. 


\begin{abstract}
Berdasarkan tes hasil belajar (postest) siswa dihitung berdasarkan jumlah siswa yang tuntas belajar dan mencapai KKM pada suatu kelas. Dari jumlah siswa sebanyak 20 orang, pada siklus I jumlah siswa yang tuntas hasil belajar KKM sebesar $45 \%$ atau 9 orang. Selanjutnya pada siklus III test hasil belajar (postest) siswa meningkat sebesar 65\% atau 13 orang. Pada siklus III test hasil belajar (postest) meningkat sebesar $85 \%$ atau 17 orang.
\end{abstract}

Sudjana (2016, hlm.22) mengemukakan bahwa dalam hasil belajar terdapat 3 aspek yaitu:

a) Ranah kognitif

Berkenaan hasil belajar intelektual yang terdiri dari enam aspek, yaitu pengetahuan atau ingatan, pemahaman, aplikasi, analisis, sintesis, dan evaluasi, kedua aspek pertama disebut kognitif tingkat rendah dan keempat aspek berikutnya termasuk kognitif tingkat tinggi.

b) Ranah afektif

Berkenaan dengan sikap yang terdiri dari lima aspek yaitu penerimaan, jawaban atau reaksi, penilaian, organisasi, dan internalisasi. Beberapa ahli mengatakan bahwa sikap seseorang dapat diramalkan perubahannya, bila seseorang telah memilki penugasan koginitif tingkat tinggi. Penilaian hasil belajar afektif kurang mendapat perhatian dari guru. Para guru lebih banyak menilai ranah kognitif sematamata. Tipe hasil belajar afektif tampak pada siswa dalam berbagai tingkah laku seperti perhatiannya terhadap pelajaran, disiplin, motivasi belajar, dan hubungan sosial.

c) Ranah psikomotor

Berkenaan dengan hasil belajar keterampilan dan kemampuan bertindak, ada enam aspek psikomotor yaitu gerakan refleks, keterampilan gerakan dasar, kemampuan perspektual,keharmonisan atau kompleks, dan gerakan ekpresif dan interpretatif.

Peningkatan tes hasil belajar (postest) dalam siklus I, II dan III yang peneliti susun dengan menggunakan model Cooperative Learning Tipe Team Accelerated 
Intruction (TAI) Pada subtema keberagaman budaya bangsaku di kelas IV SDN Komplek Karang Taruna Sari dapat dilihat pada tabel dibawah ini:

Untuk mendapatkan gambaran mengenai hasil belajar siswa pada siklus I, siklus II dan siklus III dapat dilihat dari diagram 4.3 berikut:

\section{Diagram 2 Rekapitulasi Hasil}

\section{Belajar Siswa}

\section{Siklus I, Siklus II dan Siklus III}

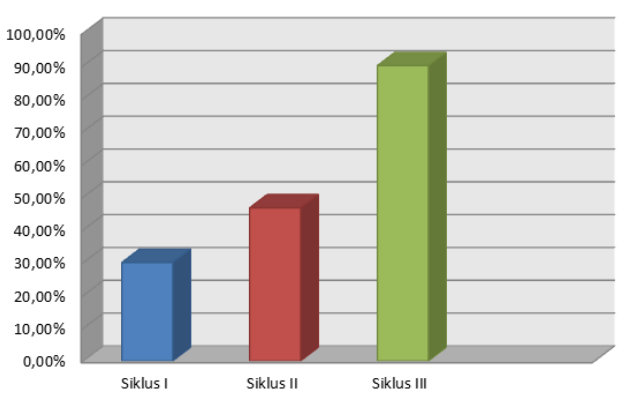

Jika dilihat dari data diatas maka pembelajaran dengan menggunakan model pembelajaran Cooperative Learning Tipe Team Accelerated Intruction (TAI) dalam pembelajaran subtema keberagaman budaya bangsaku pada siswa kelas IV SDN Komplek Karang Taruna Sari sudah mencapai target indikator keberhasilan semua variabel yang telah ditentukan.

\section{5) Lembar Wawancara}

Dari beberapa pertanyaan yang diajukan oleh peneliti kepada observer yaitu guru kelas IV, menurut observer model Cooperative Learning Tipe Team Accelerated Intruction (TAl) eefektif digunakan dalam pembelajaran pada subtema keberagaman budaya bangsaku, karena dengan model ini dapat meningkatkan antusias siswa dikarenakan pembelajaran yang dilakukan secara berkelompok dan dengan menggunakan sistem skor untuk mendapatkan kelompok yang terbaik akan mendapatkan reward sehingga siswa terlihat lebih aktif dan antusias dalam mengikuti pembelajaran dikelas. Pertanyaan yang diajukan oleh peneliti dan jawaban yang diberikan oleh observer dijelaskan pada tabel berikut:

Tabel 5

\section{Lembar Wawancara Guru}

\begin{tabular}{|c|l|l|}
\hline No. & Pertanyaan & \multicolumn{2}{|c|}{$\begin{array}{c}\text { Ringkasan } \\
\text { Jawaban }\end{array}$} \\
\hline 1. & $\begin{array}{l}\text { Bagaimana } \\
\text { pendapat } \\
\text { menurut } \\
\text { Bapak/lbu }\end{array}$ & $\begin{array}{l}\text { menurut saya } \\
\text { model ini cocok } \\
\text { digunakan untuk } \\
\text { kelas IV karena }\end{array}$ \\
\hline
\end{tabular}




\begin{tabular}{|c|c|c|}
\hline No. & Pertanyaan & $\begin{array}{c}\text { Ringkasan } \\
\text { Jawaban }\end{array}$ \\
\hline & $\begin{array}{l}\text { tentang } \\
\text { pengguaan } \\
\text { model } \\
\text { Cooperative } \\
\text { Learning Tipe } \\
\text { Team } \\
\text { Accelerated } \\
\text { Intruction } \\
\text { (TAI) di kelas } \\
\text { IV dalam } \\
\text { pembelajaran } \\
\text { subtema } \\
\text { keberagaman } \\
\text { budaya } \\
\text { bangsaku? }\end{array}$ & $\begin{array}{l}\text { dalam } \\
\text { pembelajarannya } \\
\text { dilakukan secara } \\
\text { berkelompok dan } \\
\text { membutuhkan } \\
\text { kerjasama yang } \\
\text { baik agar } \\
\text { mendapatkan } \\
\text { nilai tertinggi. }\end{array}$ \\
\hline 2. & $\begin{array}{l}\text { Bagaimana } \\
\text { respon sisea } \\
\text { setelah } \\
\text { menggunakan } \\
\text { model } \\
\text { Cooperative } \\
\text { Learning Tipe } \\
\text { Team } \\
\text { Accelerated } \\
\text { Intruction } \\
\text { (TAI)? }\end{array}$ & $\begin{array}{l}\text { Responnya baik, } \\
\text { siswa berebut } \\
\text { ingin } \\
\text { mendapatkan } \\
\text { skor tertingg } \\
\text { agar menjadi } \\
\text { kelompok } \\
\text { terbaik, mereka } \\
\text { terlihat cukup } \\
\text { antusias }\end{array}$ \\
\hline 3. & $\begin{array}{l}\text { Apakah } \\
\text { dengan } \\
\text { menggunakan } \\
\text { model } \\
\text { Cooperative } \\
\text { Learning Tipe } \\
\text { Team } \\
\text { Accelerated } \\
\text { Intruction } \\
\text { (TAl) pada }\end{array}$ & $\begin{array}{l}\text { Keaktifannya } \\
\text { meningkat } \\
\text { mereka } \\
\text { mengikuti } \\
\text { pembelajaran } \\
\text { cukup aktif, } \\
\text { dengan begitu } \\
\text { hasil belajar pun } \\
\text { ikut meningkat. }\end{array}$ \\
\hline
\end{tabular}

\begin{tabular}{|c|c|c|}
\hline No. & Pertanyaan & $\begin{array}{c}\text { Ringkasan } \\
\text { Jawaban }\end{array}$ \\
\hline & $\begin{array}{l}\text { subtema } \\
\text { keberagaman } \\
\text { budaya } \\
\text { bangsaku } \\
\text { dapat } \\
\text { meningkatkan } \\
\text { keaktifan dan } \\
\text { hasil belajar } \\
\text { siswa? }\end{array}$ & \\
\hline 4. & $\begin{array}{l}\text { Kendala } \\
\text { apakah yang } \\
\text { lbu/Bapak } \\
\text { rasakan } \\
\text { ketika } \\
\text { melakukan } \\
\text { kegiatan } \\
\text { pembelaran } \\
\text { subtema } \\
\text { keberagaman } \\
\text { budaya } \\
\text { bangsaku? }\end{array}$ & \begin{tabular}{lr} 
Masih ada \\
beberapa siswa \\
yang belum \\
tuntas mencapai \\
\multicolumn{2}{c}{ nilai KKM }
\end{tabular} \\
\hline 5. & $\begin{array}{l}\text { Bagaimana } \\
\text { saran } \\
\text { Bapak/lbu } \\
\text { untuk proses } \\
\text { pembelajaran } \\
\text { subtema } \\
\text { keberagaman } \\
\text { budaya } \\
\text { bangsaku } \\
\text { untuk } \\
\text { kedepannya? }\end{array}$ & $\begin{array}{l}\text { sepertinya } \\
\text { dengan } \\
\text { menggunakan } \\
\text { model } \\
\text { pembelajaran } \\
\text { yang efektif dan } \\
\text { sesuai dapat } \\
\text { meningkatkan } \\
\text { hasil belajar dan } \\
\text { keaktifan siswa }\end{array}$ \\
\hline \multicolumn{3}{|c|}{$\begin{array}{l}\text { Sumber:Hasil wawancara dengan } \\
\text { observer (Guru kelas IV SDN } \\
\text { Komplek Karang Taruna Sari). }\end{array}$} \\
\hline
\end{tabular}




\section{E. KESIMPULAN}

Pembelajaran menggunakan model Cooperative Learning Tipe Team Accelerated Intruction (TAI) pada setiap siklusnya mengalami peningkatan. Berdasarkan hasil penelitian dan pembahasan, maka secara umum dapat disimpulkan bahwa penggunaan model Cooperative Learning Tipe Team Accelerated Intruction (TAI) dapat meningkatkan keaktifan dan hasil belajar siswa pada tema indahnya kebersamaan

subtema

keberagaman budaya bangsaku di kelas IV SDN Komplek Karang Taruna Sari.

Dari rencana pelaksanaan pembelajaran yang disusun oleh peneliti pada tema indahnya kebersamaan subtema keberagaman budaya bangsaku di kelas IV SDN Komplek Karang Taruna Sari dapat diketahui bahwa dengan menggunakan model Cooperative Learning Tipe Team Accelerated Intruction (TAI) dapat meningkatkan keaktifan dan hasil belajar siswa dalam pembelajaran subtema keberagaman budaya bangsaku

Pelaksanaan pembelajaran dengan menggunakan model Cooperative Learning Tipe Team Accelerated Intruction (TAI) pada pembelajaran subtema keberagaman budaya bangsaku dapat meningkatkan keaktifan dan hasil belajar siswa di kelas IV SDN Komplek Karang Taruna Sari. Pelaksanaan pembelajaran berpusat pada siswa. Siswa harus dapat menentukan sendiri apa yang harus di pelajari, dan dari mana informasi harus di peroleh di bawah bimbingan guru.

Pentingnya keaktifan menumbuhkan rasa keberanian, berpartisipasi, keaktifan belajar, dan percaya diri dalam berkelompok meningkat dengan menggunakan model Cooperative Learning Tipe Team Accelerated Intruction (TAl) pada tema indahnya kebersamaan subtema keberagaman budaya bangsaku di kelas IV SDN Komplek Karang Taruna Sari. Hal ini terlihat dari setiap siklusya, pada siklus I siswa yang mencapai KKM sebanyak 6 
orang dari 30 siswa. Pada siklus II siswa yang mencapai KKM meningkat sebanyak 14 orang. Pada siklus III siswa yang mencapai KKM sebanyak 17 orang.

Peningkatan hasil belajar siswa pada tema indahnya kebersamaan subtema keberagaman budaya bangsaku dengan menggunakan model Cooperative Learning Tipe Team Accelerated Intruction (TAI) terlihat sangat signifikan. Hal ini terlihat dari peningkatan setiap siklusnya, pada siklus I siswa yang mencapai KKM sebanyak 9 orang dari 30 puluh orang siswa atau jika dipresentasekan. Pada siklus II siswa yang mencapai KKM meningkat sebanyak 13 orang.

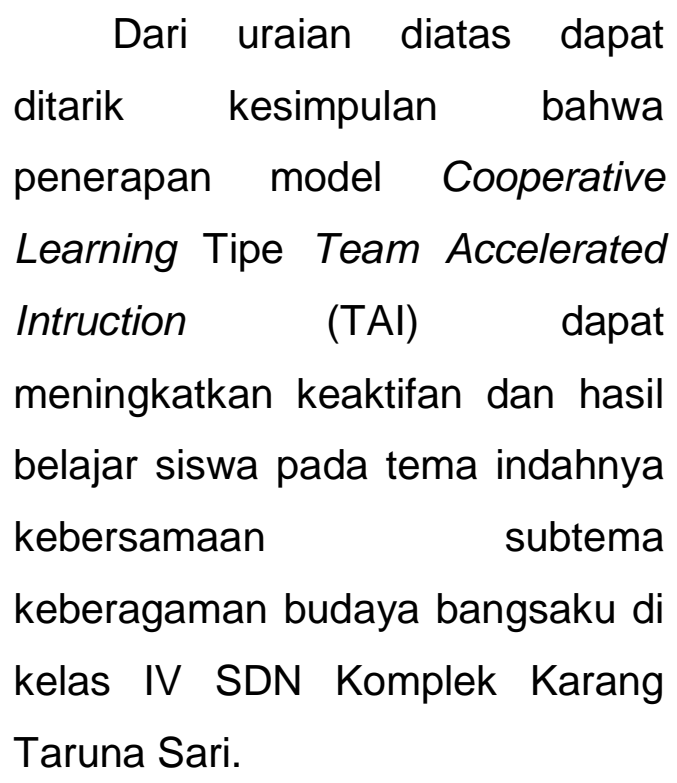

Dari uraian diatas dapat ditarik kesimpulan bahwa Learning Tipe Team Accelerated Intruction (TAl) dapat meningkatkan keaktifan dan hasil belajar siswa pada tema indahnya keberagaman budaya bangsaku di Taruna Sari.

\section{DAFTAR PUSTAKA}

Asriningsih, K. (2015). Pengaruh Model Pembelajaran

Kooperatif Tipe Team Assisted Individualization (TAI) Terhadap Hasil Belajar IPA Siswa Kelas IV SD Gugus $\checkmark$ Kecamatan Banjar. Diakses dari halaman web tanggal 30 April 2017 dari: http://ejournal.undiksha.ac.id/i ndex.php/

JJPGSD/article/view/2327

Aryani, (2014). Pengaruh Model Pembelajaran TAl Terhadap Keterampilan Berpikir Kritis IPS Siswa Kelas V SD di Desa Kaliasem Kecamatan Banjar. Diakses dari halaman web tanggal 30 April 2017 dari: http://ejournal.undiksha.ac.id/i ndex.php/JJPGSD/article/vie wFile/2429/2102

Anggraeni, D. (2014). Peningkatan Kualitas Pembelajaran IPS Melalui Model Pembelajaran Kooperatif Tipe Course Review Horay Pada Siswa Kelas IV SD Negeri Sekaran 01 Semarang. Diakses dari halaman web tanggal $01 \mathrm{Mei}$ 2017 dari: https://journal.unnes.ac.id/nju /index.php/ kreatif/article/viewFile/1681/1 887

Aritohang, K. (2016). Minat dan Motivasi dalam Meningkatkan Hasil Belajar Siswa. Diakses 
dari halaman web tanggal 27

Mei 2017 dari:

http://s3.amazonaws.com/aca demia.edu.documents/35904 799/Hal._11.pdf

Aqib, Zainal. (2013). Model-model, Media, dam Strategi Pembelajaran Kontekstual (Inovatif). Bandung: Yrama Widya

Arikunto, S. (2012). Penelitian Tindakan Kelas. Jakarta: Bumi Aksara

Baskara, B. (2014). Penerapan Metode Quiz Untuk Meningkatkan Keaktifan dan Hasil Belajar Siswa Kelas V Pada Mata Pelajaran IPA SD Negeri II Tekaran. Diakses dari halaman web tanggal 28 April 2017 dari: http://eprints.ums.ac.id/17110 /1/02._906532568865/.pdf

Djamarah, S. (2013). Strategi Belajar Mengajar. Jakarta: Rineka Cipta

FKIP Universitas Padundan. (2017). Panduan Praktlk Pengalaman Lapangan. Universitas Pasundan Bandung.

Hamalik (2014). Psikologi belajar mengajar. Bandung: Sinar Baru Algesindo

Harianto, S. (2014). Belajar dan Pembelajaran. Bandung: Remaja Rosdakarya
Huda, M. (2014). Cooperative Learning. Yogyakarta: Pustaka Pelajar

Heriawan, A, dkk. (2012). Metodologi Pembelajaran. Banten: LP3G

Isjoni, (2011). Cooperative Learning. Bandung: Alfabeta

Indriani, A. (2015). Efektifitas Model Pembelajaran Tipe Team Assisted Individual (TAl) Dan Thingk Pair Share (TPS) ditinjau Dari Sikap Percaya Diri Peserta didik Pada Matematika SDN Kota Kediri Tahun Ajaran 2014/2015. Diakses dari halaman web tanggal 28 Mei 2017 dari: https://eprints.uns.ac.id/8119/ 1/218550811201103581.pdf

Jufri, W. (2017). Belajar dan Pembelajaran SAINS. Bandung: Pustaka Reka Cipta Jamil, S. (2016). Strategi Pembelajaran. Yogyakarta: Ar-ruzz Media

Kusnawan, D. (2013). Analisis Belajar, Program Perbaikan dan Program Pengayaan. Depok: Luxima

Kosasih, (2014). Strategi Belajar dan Pembelajaran Implementasi Kurikulum 2013. Bandung: Yrama Widya. Kemendikbud, Draft Kurikulum 2013

Kurniawati. (2014). Penerapan Model Kooperative Tipe Team 
Assisted Individualization

(TAI) Untuk Meningkatkan Keaktifan dan Prestasi Belajar Matematika kelas $V$ SDN Yappi Mulusan Paliyan Gunung Kidul. Diakses dari halaman web tanggal 14 Mei 2017 dari: http://eprints.ums.ac.id/8677/ 2/A210060103.pdf

Nikadek, A. (2014). Pengaruh Model Pembelajaran TAI Terhadap Keterampilan Berpikir Kritis IPS Siswa Kelas $\checkmark$ SDN Desa Kaliasem Kecamatan Banjar. Diakses dari halaman web tanggal 28 Mei 2017 dari: http://ejournal.undiksha.ac.id/i ndex.php/JJPGSD/article/vie wFile/2429/2102

Novilia, A. (2015). Penerapan Model Pembelajaran Kooperatif Tipe TAI Team Assisted Individualization Untuk Meningkatkan Keaktifan Belajar Matematika Pada Siswa Kelas IV SD Negri Mojosari Karanggede Boyolali Tahun Ajaran 2014/2015. Diakses dari halaman web tanggal 27 mei 2017 dari: http://journal.ums.ac.id/index. php/jk/article/ download/503/366

Nuriman, dkk. (2014). Jurnal IImu Pendidikan Sekolah Dasar. Diakses dari halaman web tanggal 29 Mei 2017 dari: http://ejournal.undiksha.ac.id/ index.php/JJPGSD/article/vie wFile/3065/2538

Rusmono, (2014). Strategi Pembelajaran dengan Problem Based Learning. Bogor: Ghalia Indonesia

Rahmatikasari, dkk. (2014). Penerapan Tipe Team Assisted Individualization (TAI) Dalam Peningkatan Pembelajaran Matematika Tentang Bilangan Pecahan Siswa Kelas V SD. Diakses dari halaman web tanggal 27 Mei $2017 \quad$ dari http://jurnal.fkip.uns.ac.id/inde x.php/pgsdkebumen/article/ view/1763

Rahmawati, D. (2014). Keefektifan Pembelajaran Kooperatif STAD dan TAl ditinjau Dari Aktivitas dan Prestasi Belajar Matematika Siswa. Diakses dari halaman web tanggal 19 mei 2017 dari: http://journal.uny.ac.id/ index.php/jpe/article/viewFile/ 2648/2202

Sudjana, N. (2016). Penilaian Hasil Proses Belajar Mengajar. Bandung: PT Remaja Rosdakarya

Slavin, R. (2015). Cooperative Learning. Bandung: Penerbit Nusa Media

Shoimin, A. (2014). 68 Model Pembelajaran Inovatif dalam 
Kurikulum 2013. Yogyakarta:

Ar-ruzz Media

Sagala, S. (2010). Konsep dan Makna Pembelajaran.

Bandung : Alfabeta

Suprijono, A. (2014). Cooperative Learning Teori dan Aplikasi Paikem. Yogyakarta: Pustaka Pelajar.

Susanto, J. (2015). Pengembangan

Perangkat Pembelajaran Berbasis Lesson Study Dengan Kooperative Tipe Numbered Heards Together Untuk Meningkatkan Aktivitas dan Hasil Belajar IPA di SD. Diakses dari halaman web tanggal 01 juni 2017 dari: https://journal.unnes.ac.id/sju/ index.php/jpe/article/view/785

Sutriningsih, N. (2014). Model Pembelajarn Team Assisted Individualization Berbasis Assesment For Learning Pada Persamaan Garis Lurus Ditinjau dari Karakteristik Cara Berpikir. Diakses dari halaman web tanggal 01 Juni 2017 dari: http://ejournal.stkipmpringsew ulpg.ac.id/index.php /edumath/article/view/81

Thobroni, M. Belajar dan Pembelajaran. (2015).

Yogyakarta: Arruz Media.

UU Sistem Pendidikan Nasional Tahun 2003. Diakses dari halaman web tanggal 28 April
2017

dari: http://sindikker.dikti.go.id/dok/ UU/UU20-2003-sisdiknas.pdf

UU Guru dan Dosen No.14 Tahun 2005. Diakses dari halaman web tanggal 28 April 2017 dari:

http://sindikker.dikti.go.id/dok/ UU/UUNo.142005(guru\%20 \%dosen.pdf)

Utami, F. (2015). Pengaruh Model Pembelajaran Kooperatif Tipe TAI (Team Assisted Individualization) dalam Pembelajaran IPA Materi Gaya Terhadap Hasil Belajar Siswa Kelas IV SD Negeri Panembahan Yogyakarta. Diakses dari halaman web tanggal 28 Mei 2017 dari: https://journal.unnes.ac.id/nju /index.php/kreatif/article/view File/1681/1887

Vitasari, R. (2014). Peningkatan Keaktifan dan Hasil Belajar Matematika Melalui Model Problem Based Learning Siswa Kelas V SD Negri Kutosari. Diakses dari halaman web tanggal $20 \mathrm{Mei}$ 2017 dari: http://jurnal.fkip.uns.ac.id/inde x.php/pgsdkebumen/article/vi ew/2226

Wulandari, P (2015). Pengaruh Penerapan Model Pembelajaran Kooperatif Tipe Team Accelerated Intruction (TAI) Terhadap Hasil Belajar 
IPS Siswa Kelas V SD Gugus

VIII Kedewetan. Diakses dari halaman web tanggal $21 \mathrm{Mei}$ 2017 dari: http://repository.uksw.edu/bits tream/123456789/ 1881/3/T1_202008068BAB\% 20Il.pdf

Wahyuning, A (2015). Pengaruh Model Pembelajaran Kooperatif Tipe TAl Dengan Teknik Tutor Sebaya Terhadap Prestasi Belajar Matematika Dengan Pengendalian Kemampuan Penalaran Formal Siswa Kelas VIII Bilingual SMP RSBI Denpasar. Diakses dari halaman web tanggal 01 Juni
2017

dari:

http://ejournal.undiksha.ac.id/i ndex.php/

JJPGSD/article/viewFile/3065 /2538

Wibawa, S. (2014). Penelitian Tindakan Kelas. Diakses dari halaman web tanggal 20 mei 2017 dari: http://staff.uny.ac.id/sites/defa ult/files/pengabdian/drsutrisna-wibawa$\mathrm{mpd} /$ penelitian-tindakankelas-plpg2012.pdf

Wardani. (2014). Hakikat Penelitian Tindakan Kelas. Diakses dari halaman web tanggal 19 mei 2017 dari: http://repository.ut.ac.id/4153/ 1/IDIK4008-M1.pdf 